\title{
Enhanced Light Scattering by Preferred Orientation Control of Ga Doped ZnO Films Prepared through MOCVD
}

\author{
Long Giang Bach, ${ }^{1}$ Nam Giang Nguyen, ${ }^{2}$ and Van Thi Thanh $\mathrm{Ho}^{3}$ \\ ${ }^{1}$ NTT Institute of Hi-Technology, Nguyen Tat Thanh University, Ho Chi Minh City 70000, Vietnam \\ ${ }^{2}$ Thin Film Solar Cells Laboratory, Department of Chemical Engineering, National Taiwan University of \\ Science and Technology (NTUST), Taipei City 106, Taiwan \\ ${ }^{3}$ Ho Chi Minh City University of Natural Resources and Environment (HCMUNRE), Ho Chi Minh City 70000, Vietnam
}

Correspondence should be addressed to Van Thi Thanh Ho; httvan@hcmunre.edu.vn

Received 6 April 2016; Accepted 15 May 2016

Academic Editor: Prakash Basnyat

Copyright (C) 2016 Long Giang Bach et al. This is an open access article distributed under the Creative Commons Attribution License, which permits unrestricted use, distribution, and reproduction in any medium, provided the original work is properly cited.

\begin{abstract}
We have explored the effective approach to fabricate $\mathrm{GZO} / \mathrm{ZnO}$ films that can make the pyramidal surface structures of GZO films for effective light scattering by employing a low temperature $\mathrm{ZnO}$ buffer layer prior to high temperature GZO film growth. The GZO thin films exhibit the typical preferred growth orientations along the (002) crystallographic direction at deposition temperature of $400^{\circ} \mathrm{C}$ and SEM showed that column-like granule structure with planar surface was formed. In contrast, GZO films with a pyramidal texture surface were successfully developed by the control of (110) preferred orientation. We found that the light diffuse transmittance of the film with a GZO $(800 \mathrm{~nm}) / \mathrm{ZnO}(766 \mathrm{~nm})$ exhibited $13 \%$ increase at $420 \mathrm{~nm}$ wavelength due to the formed large grain size of the pyramidal texture surface. Thus, the obtained GZO films deposited over ZnO buffer layer have high potential for use as front TCO layers in Si-based thin film solar cells. These results could develop the potential way to fabricate TCO based $\mathrm{ZnO}$ thin film using MOCVD or sputtering techniques by depositing a low temperature $\mathrm{ZnO}$ layer to serve as a template for high temperature GZO film growth. The GZO films exhibited satisfactory optoelectric properties.
\end{abstract}

\section{Introduction}

As a front contact for silicon based thin film solar cells, the Transparent Conductive Oxide (TCO) layers on glass should not only possess satisfactory optoelectric properties, but also exhibit light trapping capability to increase the light absorption within the active layers [1-3]. Textured surface on TCO layers is usually designed to scatter the incident light to elongate the pathway of light and subsequently increase the short circuit current density $\left(J_{\text {sc }}\right)$ by $20 \sim 40 \%$ in the solar cells [4-6]. Recently, several techniques were developed for obtaining surface textures. One of the common methods was the wet-etching of sputtered Al-doped $\mathrm{ZnO}$ (AZO) films by using acid treatment to create crater-like structure by which the light scattering is increased. Nevertheless, this process costs highly due to the thick AZO film sputtering $(\sim 1 \mu \mathrm{m})$. Furthermore, complicated treatments are required to obtain textured topography, like soaking in an acid solution, lithography, and so forth, which increase the fabrication cost and accompany the risk of introducing unexpected impurities $[7,8]$ into the TCO layers. Moreover, atmosphere pressure chemical vapor deposition (APCVD) of F-doped $\mathrm{SnO}_{2}$ and low-pressure chemical vapor deposition (LPCVD) of Bdoped $\mathrm{ZnO}$, which exhibited pyramidal crystalline habits on the film surface and thus are capable of scattering the incident light, were also proposed [9-13].

In this work, we explored the methodology to increase the light diffuse transmittance through controlling the preferred orientation of polycrystalline Ga doped $\mathrm{ZnO}$ (GZO) films grown by the low-pressure chemical vapor deposition (LPCVD) technique using diethyl zinc (DEZn) and trimethyl gallium (TMGa) as the $\mathrm{Zn}$ and Ga precursors, respectively. Different from the low process temperature $\left(\sim 150^{\circ} \mathrm{C}\right)$ of $\mathrm{B}$ doped $\mathrm{ZnO}$, the GZO films exhibited satisfactory optoelectric 
properties at reaction temperatures as high as $400^{\circ} \mathrm{C}$. Xray diffraction measurement indicated that major growth direction was (002) plane and secondary electron microscopy showed that column-like granule structure with planar surface was formed. By depositing a low temperature $\mathrm{ZnO}$ layer to serve as a template for high temperature GZO film growth, the main preferred orientation of the GZO films was manipulated to (110) plane and the film surface to the pyramidlike structure. Through this two-step growth, the light diffuse transmittance of the film with a GZO $(\sim 800 \mathrm{~nm}) / \mathrm{ZnO}$ $(766 \mathrm{~nm})$ combination exhibited $13 \%$ increase at $420 \mathrm{~nm}$ wavelength due to the preservation of the pyramidal surface morphology.

\section{Results and Discussion}

2.1. Effect of Growth Temperature on the Crystalline Orientation of GZO Films. First of all, the GZO films were grown at various deposition temperatures to explore the effects of growth temperature and growth rate on the orientation of the GZO films. The detailed experiment was carried out as our previous work [14]. The XRD measurement was used to determine the crystalline orientation of the GZO films deposited. Figure 1 reveals the XRD patterns of the GZO films grown at various substrate temperatures. Started from (110) plane orientation at low temperatures like $300^{\circ} \mathrm{C}$, the main crystalline orientation changed to (002) plane when the substrate was raised to $400^{\circ} \mathrm{C}$. When further raised to $450^{\circ} \mathrm{C}$, all the crystalline planes including (100), (101), (002), and (110) appeared. With increasing temperature from 300 to $350^{\circ} \mathrm{C}$, the growth mode of GZO film was already in the diffusion controlled regime (Figure 2). So the surface with the highest absorption rate will dominate the film growth orientation [15, 16]. As a result, the (002)-oriented films could be obtained due to the enhancement of surface diffusion [17]. At further high temperature like $450^{\circ} \mathrm{C}$, all crystal planes appeared because the surface collision rate is rate controlling; thereby all planes could appear. The intensity ratio of (002) plane for GZO film with substrate temperature $400^{\circ} \mathrm{C}$ increases by large amount compared to GZO film with substrate temperature $350^{\circ} \mathrm{C}$ due to the higher substrate temperature and the higher crystalline so that the intensity of (002) plane for GZO film with substrate temperature $400^{\circ} \mathrm{C}$ is higher than the $\mathrm{GZO}$ film with substrate temperature $350^{\circ} \mathrm{C}$. Besides, the (002) plane is preferred to grow at substrate temperature $400^{\circ} \mathrm{C}$ than the other planes.

Figure 2 shows the Arrhenius plot of the film growth rate of GZO at various substrate temperatures. It has been demonstrated that the growth of GZO film is characterized by three regimes. For low temperature (below $250^{\circ} \mathrm{C}$ ) the film growth rate increases exponentially with substrate temperature according to an Arrhenius behavior in which the deposition rate is controlled by an activated process such as adsorption, surface diffusion, chemical reaction, and desorption. The growth rate is thus controlled by mass transfer and reaction kinetics. The net activation energy for the $\mathrm{ZnO}$ thin films deposition in this region is calculated to be $\sim 3.95 \mathrm{kcal} \mathrm{mol}^{-1}$. Moreover, the growth rate is also proportional to the surface density of the unit structure $\left(N_{s}\right)$, meaning that the

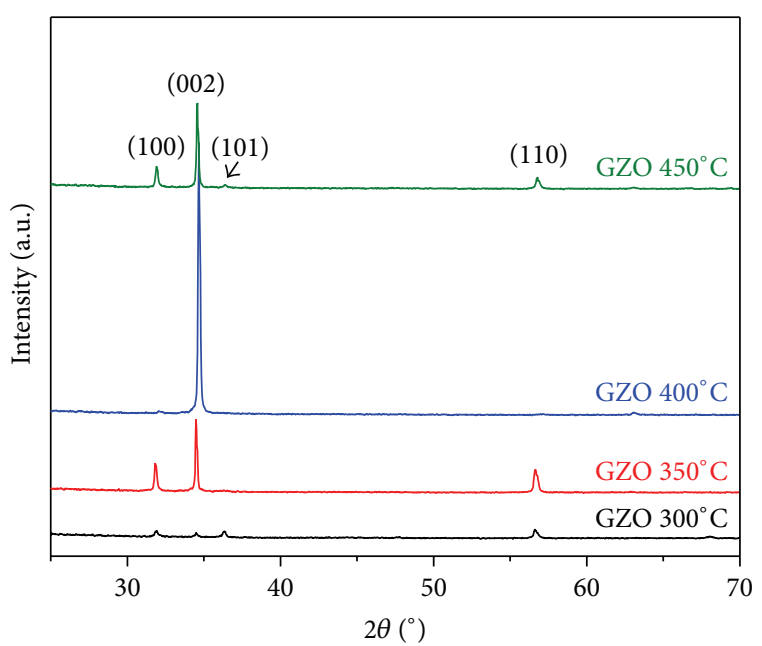

FIGURE 1: X-ray diffraction patterns of GZO film as a function of deposition temperature.

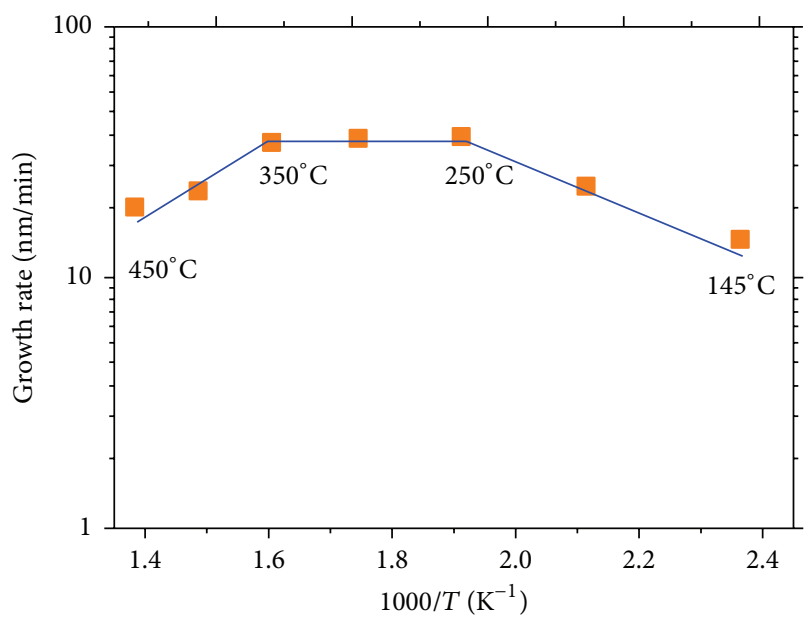

FIgURE 2: Arrhenius plot of the film growth rate of GZO film against the reciprocal of the absolute temperature.

most densely packed plane grows the fastest [14-16]. In the intermediate zone $\left(250-350^{\circ} \mathrm{C}\right)$, the growth rate reaches its maximum and remains constant, indicating that the growth rate is diffusion limited, which leads to the fact that the crystallographic plane with the highest absorption rate grows the fastest. At higher temperatures (above $350^{\circ} \mathrm{C}$ ), the logarithmic plot shows a negative slope. At these temperatures, the precursor solvent vaporizes away from the substrate and the precursor chemical reaction is carried out in the vapor phase. The growth mechanism is thus controlled by the surface collision. We found that the (002) preferred orientation of GZO film could be controlled by adjusting the deposition temperature and growth rate. However, the (110) preferred orientation that presents for the pyramidal-like structure could not be controlled within these conditions. According to these issues, we develop a methodology to control the (110) preferred orientation of GZO films by employing a low temperature of $\mathrm{ZnO}$ layer before high temperature GZO growth. 
TABLE 1: The atomic density of some common planes for $\mathrm{ZnO}$.

\begin{tabular}{lll}
\hline Crystal plane & $(110)$ & $(100)$ \\
\hline $\begin{array}{l}\text { Surface atomic density }\left(\mathrm{N}_{s}\right) \\
\left.\text { (atom } / \mathrm{cm}^{2}\right)\end{array}$ & $0.22 \times 10^{16}$
\end{tabular}

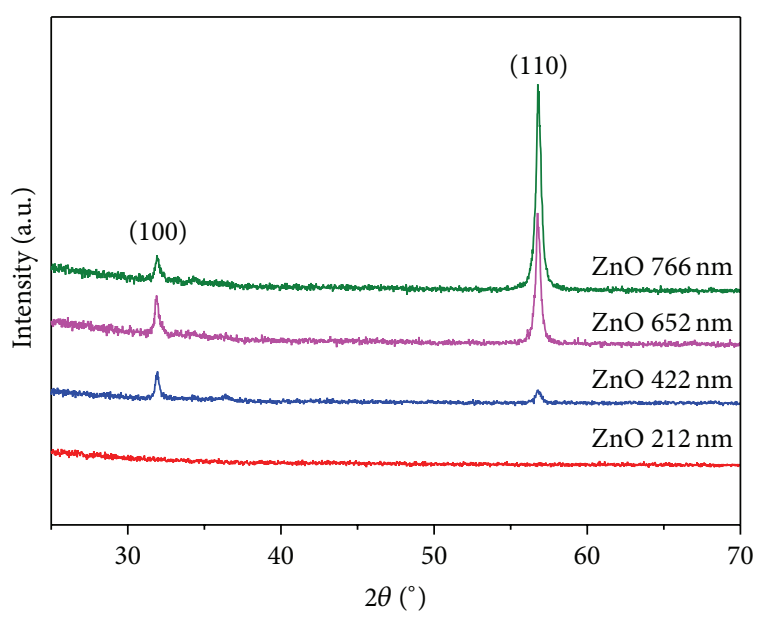

FIGURE 3: Structural properties of $\mathrm{ZnO}$ films at various thicknesses. The deposition temperature was $146^{\circ} \mathrm{C}$.

\subsection{Effect of ZnO Buffer Layer Thicknesses on the Orientation} of GZO Films. Figure 3 illustrates the evolution XRD patterns for the first step growth of $\mathrm{ZnO}$ layers at various film thicknesses. At a low growth temperatures of $146^{\circ} \mathrm{C}$, the films thicker than $212 \mathrm{~nm}$ exhibited two diffraction peaks at a value of $2 \theta$ of 31.8 and $56.8^{\circ}$, corresponding to the (100) and (110) plane of hexagonal $\mathrm{ZnO}$. When the film thickness is less than $212 \mathrm{~nm}$, no diffraction peaks were observed due to the amorphous nature. Generally for low growth temperature of $\mathrm{ZnO}$ by LPCVD at about $150^{\circ} \mathrm{C}$, the preferred orientation of $\mathrm{ZnO}$ films is (110) plane, which is evident when the film thickness is larger than $\sim 200 \mathrm{~nm}$. This result is understandable because the film growth at this temperature is controlled by surface reaction, by which the crystalline plane with the highest surface atomic density $\left(N_{s}\right)$ is formed favorably. As a result, the (110) plane would be preferred for hexagonal $\mathrm{ZnO}$ because it has the highest surface atomic density compared with (100) and (002) plane as shown in Table 1.
Figure 4 demonstrates the effect of the $\mathrm{ZnO}$ buffer layer thickness on the natively textured surface of $\mathrm{ZnO}$ films prepared at $146^{\circ} \mathrm{C}$. As can be seen in Figure 4, all the $\mathrm{ZnO}$ thin films surfaces were pyramid-like grain and the grain size was increased together with the increase of $\mathrm{ZnO}$ film thickness. These results clearly indicated that the surface grain size of $\mathrm{ZnO}$ films could be modified by adjusting the $\mathrm{ZnO}$ thickness. Consequently, the GZO films were grown at $400^{\circ} \mathrm{C}$ onto the various $\mathrm{ZnO}$ buffer layer thicknesses.

The crystal structure and orientation of the as-deposited GZO thin film grown on various thickness of $\mathrm{ZnO}$ buffer layer were investigated using $\mathrm{XRD}$ and the results are depicted in Figure 5. It is worthy to note that a strong (002) peak was observed for GZO film growth onto a thin $\mathrm{ZnO}$ buffer layer $(\sim 30 \mathrm{~nm})$, indicating the GZO film is highly oriented with its crystallographic c-axis perpendicular to the substrate. This is because the thin $\mathrm{ZnO}$ buffer layer plays a role as a seed layer for the GZO film growth and thus there is no significant change in the orientation of GZO film. However, with the increasing in $\mathrm{ZnO}$ buffer layer thickness, the preferred orientation changes from the plane with minimum surface energy (002) to the plane with relatively high surface energy (110). This can be explained due to the forming of (110) structure of $\mathrm{ZnO}$ buffer layer served as an energy barrier and thus the (110) preferred orientation of GZO film grown on (110) plane is easier than other crystal planes. Evidently, GZO thin films used $\mathrm{ZnO}$ as buffer layer whose thickness is thicker than $212 \mathrm{~nm}$ are favorable to promote the GZO film growth along (110) preferred orientation. These results conclude that $\mathrm{ZnO}$ buffer layer plays an important role in the change of growth direction of GZO film. Further, we studied the effect of deposition temperature of GZO on orientation of GZO film growth by using a thick $422 \mathrm{~nm} \mathrm{ZnO}$ buffer layer as a template. Figure 6(a) depicts the structure and orientation of $\mathrm{GZO} / \mathrm{ZnO}(422 \mathrm{~nm})$ films grown at different deposition temperature.

Obviously, the orientation of GZO film growth was preferred to (100) and (110) plane in which (110) is the 


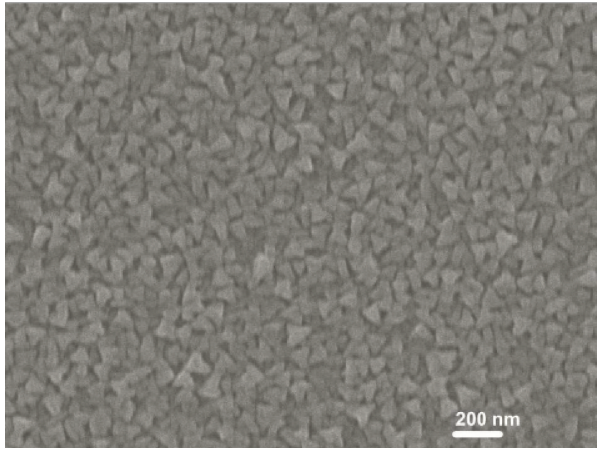

(a)

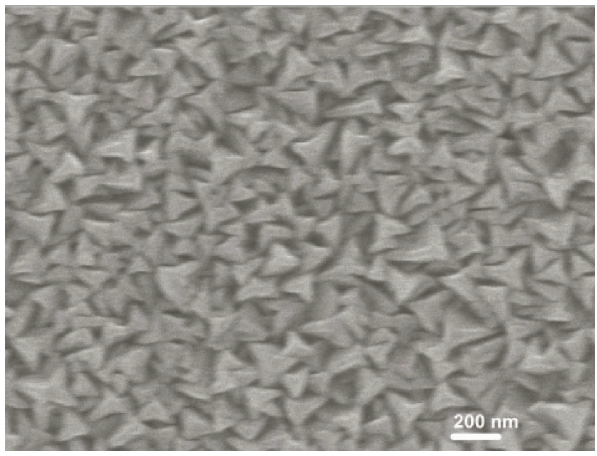

(c)

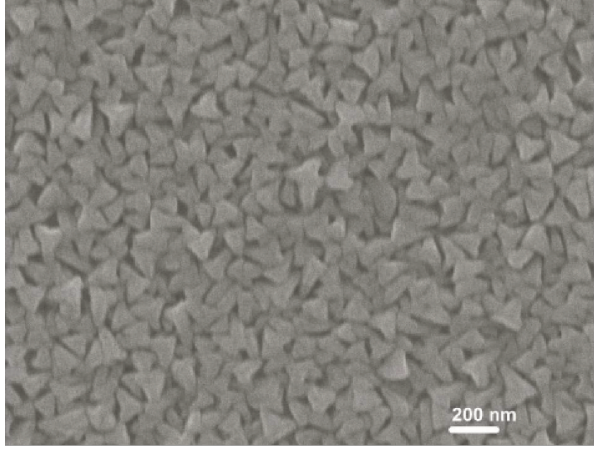

(b)

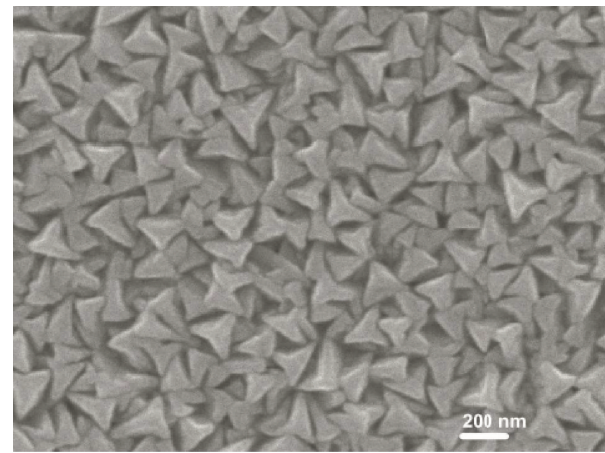

(d)

FIGURE 4: Surface morphology of ZnO films at various thicknesses: (a) $212 \mathrm{~nm}$, (b) $422 \mathrm{~nm}$, (c) $652 \mathrm{~nm}$, and (d) $766 \mathrm{~nm}$. The deposition temperature was $146^{\circ} \mathrm{C}$.

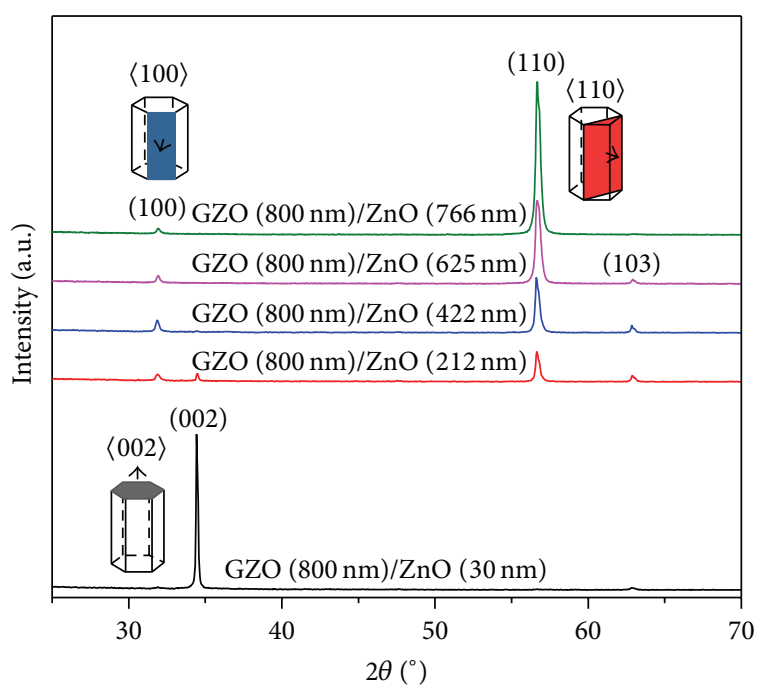

Figure 5: X-ray diffraction patterns of the GZO film growth on different thickness of $\mathrm{ZnO}$ buffer layer. The deposition temperature of GZO film was $400^{\circ} \mathrm{C}$.

main crystal plane, as shown in Figure 6. This result implies that the orientation of GZO film growth might not have been influenced by deposition temperature. The intensity of (100) peak was increased slightly with increasing deposition temperature. From the change of (100) intensity ratio, we

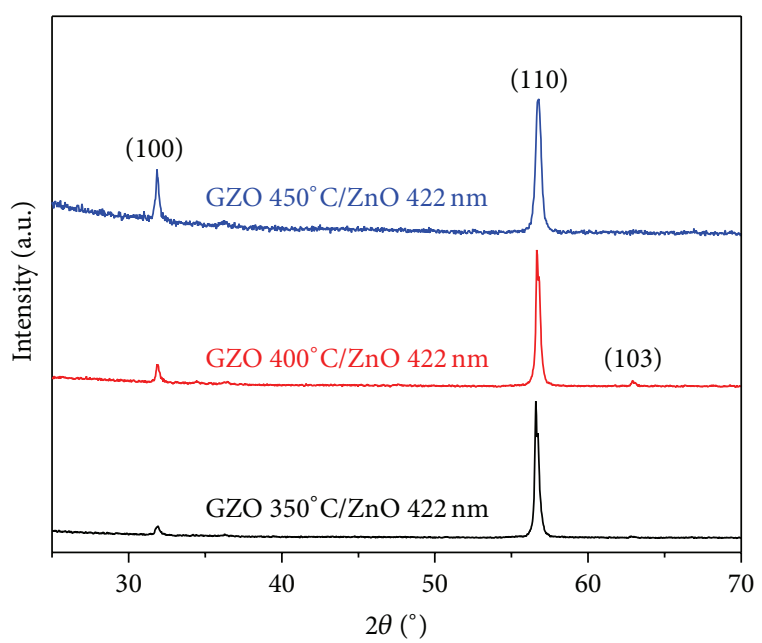

FIGURE 6: X-ray diffraction patterns of the GZO film grown on a thick $422 \mathrm{~nm} \mathrm{ZnO}$ buffer layer at different deposition temperature.

can estimate the activation energy barrier for (100) plane through the Arrhenius plot of (100) intensity ratio at different deposition temperature.

Figure 7 shows the Arrhenius plot of (100) intensity ratio between 350 and $450^{\circ} \mathrm{C}$. From the plot, the activation energy barrier $E_{\mathrm{a}}=-8.314 \times$ slope $(\mathrm{J} / \mathrm{mol})$. The activation energy barrier for (100) crystal plane was estimated 


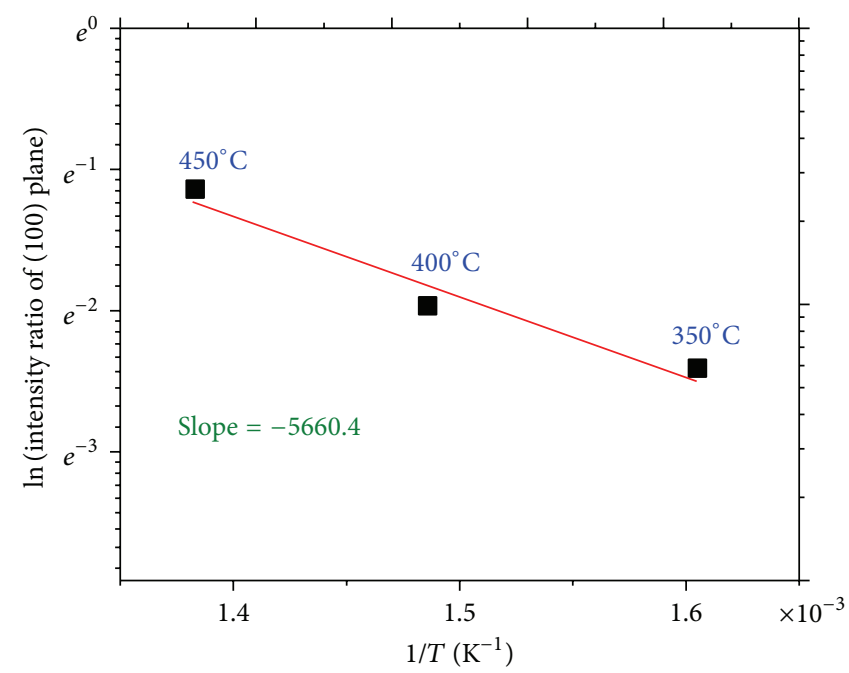

Figure 7: The Arrhenius plot of intensity ratio of (100) crystal plane of the GZO film grown on a thick $422 \mathrm{~nm}$ ZnO buffer layer against the reciprocal of the absolute temperature.

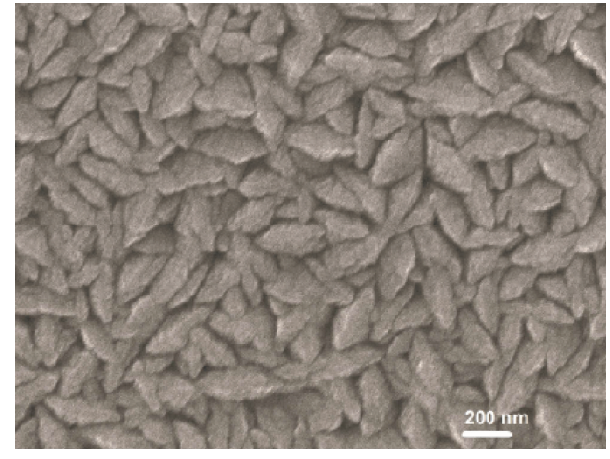

(a)

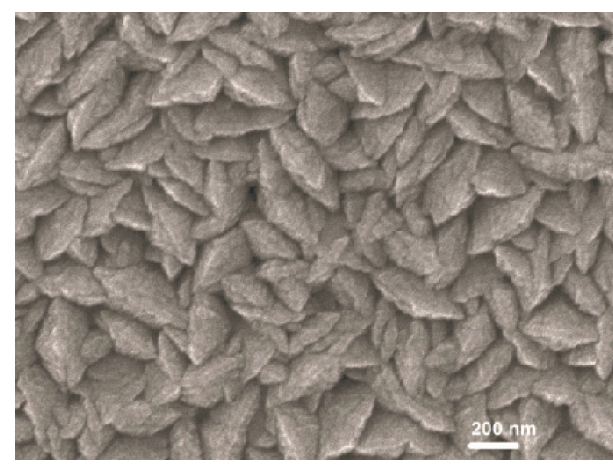

(c)

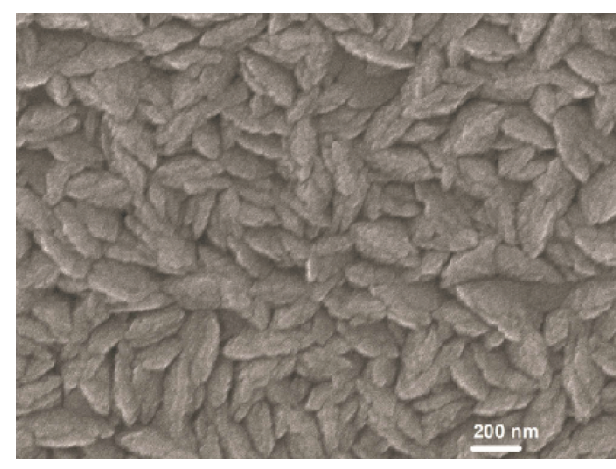

(b)

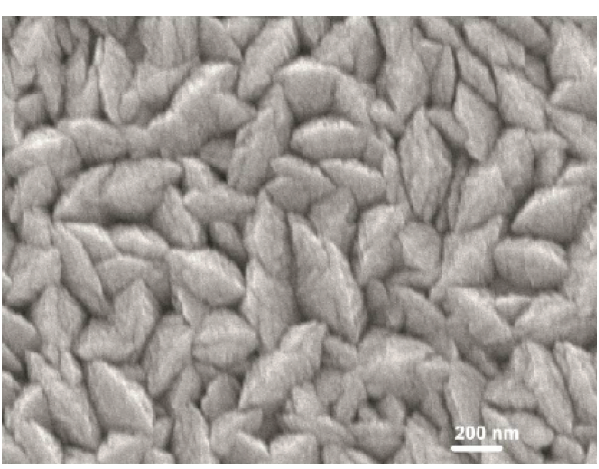

(d)

FiguRE 8: Surface morphology of GZO film with thickness $\sim 800 \mathrm{~nm}$ on different ZnO buffer layer thicknesses: (a) $212 \mathrm{~nm}$, (b) $422 \mathrm{~nm}$, (c) $652 \mathrm{~nm}$, and (d) $766 \mathrm{~nm}$. The deposition temperature of GZO film was $400^{\circ} \mathrm{C}$.

$\sim 11.24 \mathrm{kcal} \mathrm{mol}^{-1}$, which is higher than that observed for film growth $\left(3.9 \mathrm{kcal} \mathrm{mol}^{-1}\right)$. This result indicates that the (100) crystal plane could be controlled at high temperature deposition.
Figures 8(a)-8(d) reveal typical SEM images of natively textured surface GZO thin films deposited on various thickness of $\mathrm{ZnO}$ buffer layer. The GZO films grown on different $\mathrm{ZnO}$ buffer layer exhibit a well-textured morphology 
TABLE 2: Summary of the electrical properties of GZO films prepared at $400^{\circ} \mathrm{C}$ on various $\mathrm{ZnO}$ buffer layer thickness.

\begin{tabular}{lccc}
\hline Samples & Resistivity $(\Omega \mathrm{cm})$ & Mobility $\left(\mathrm{cm}^{2} \mathrm{~V}^{-1} \mathrm{~s}^{-1}\right)$ & Bulk concentration $\left(\mathrm{cm}^{-3}\right)$ \\
\hline GZO $(800 \mathrm{~nm}) / \mathrm{ZnO}(30 \mathrm{~nm})$ & $5.3 \times 10^{-4}$ & 16.25 & $7.3 \times 10^{20}$ \\
GZO $(800 \mathrm{~nm}) / \mathrm{ZnO}(212 \mathrm{~nm})$ & $5.5 \times 10^{-4}$ & 16.10 & $7.1 \times 10^{20}$ \\
GZO $(800 \mathrm{~nm}) / \mathrm{ZnO}(422 \mathrm{~nm})$ & $5.7 \times 10^{-4}$ & 16.30 & $6.8 \times 10^{20}$ \\
GZO $(800 \mathrm{~nm}) / \mathrm{ZnO}(652 \mathrm{~nm})$ & $5.8 \times 10^{-4}$ & 16.35 & $6.7 \times 10^{20}$ \\
GZO $(800 \mathrm{~nm}) / \mathrm{ZnO}(766 \mathrm{~nm})$ & $5.9 \times 10^{-4}$ & 16.45 & $6.5 \times 10^{20}$ \\
\hline
\end{tabular}

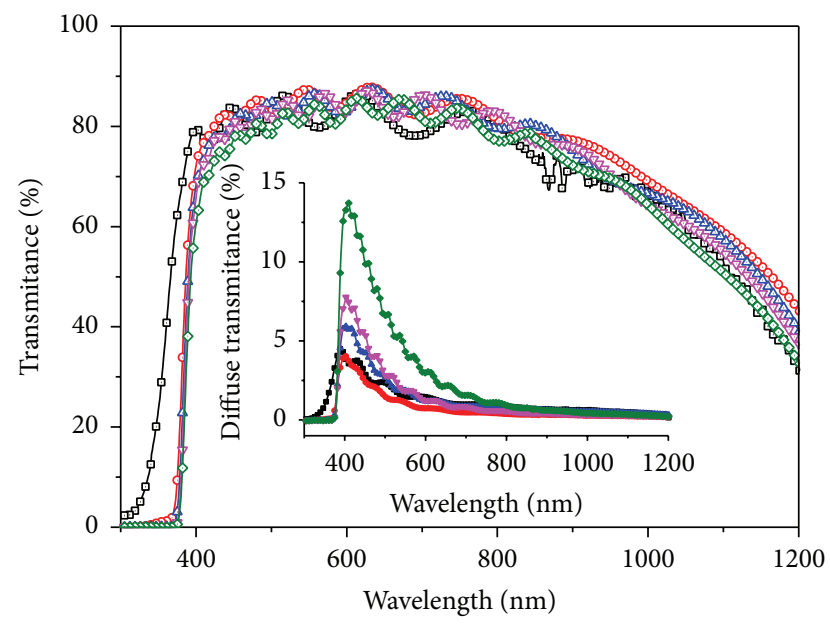

$\multimap \operatorname{GZO}(800 \mathrm{~nm}) / \mathrm{ZnO}(30 \mathrm{~nm}) \rightarrow \operatorname{GZO}(800 \mathrm{~nm}) / \mathrm{ZnO}(625 \mathrm{~nm})$

$\multimap \operatorname{GZO}(800 \mathrm{~nm}) / \mathrm{ZnO}(212 \mathrm{~nm}) \multimap \mathrm{GZO}(800 \mathrm{~nm}) / \mathrm{ZnO}(766 \mathrm{~nm})$

$\rightarrow$ GZO $(800 \mathrm{~nm}) / \mathrm{ZnO}(422 \mathrm{~nm})$

Figure 9: Optical properties of GZO film with thickness $\sim 800$ $\mathrm{nm}$ on different $\mathrm{ZnO}$ buffer layer thicknesses. The deposition temperature of GZO film was $400^{\circ} \mathrm{C}$.

with pyramidal texture surface, confirming that the highly textured morphology of the GZO films is preserved well after two-step growth. The surface morphology of the GZO $(800 \mathrm{~nm}) / \mathrm{ZnO}(766 \mathrm{~nm})$ film shows the largest pyramidal grain size, indicating that the grain size of GZO layer strongly depends on the grain size of $\mathrm{ZnO}$ buffer layer.

The optical properties illustrate the transmittance and light trapping efficiency of the bilayer GZO $(800 \mathrm{~nm}) / \mathrm{ZnO}$ films. As shown in Figure 9, the average optical transmittances were over $80 \%$ at the wavelength from 400 to $800 \mathrm{~nm}$. However, the transmittance of the films decreased slightly in the long-wavelength range above $1000 \mathrm{~nm}$ because of the absorption of free carriers in the $\mathrm{ZnO}$ films caused by gallium doping. As shown and indicated by Figures 8-9, the light scattering properties had a good relationship with the surface morphologies. The thicker the $\mathrm{ZnO}$ buffer layer, the higher the diffuse transmittance that was obtained due to the increasing of surface texture grain size. This suggests that the facile way to improve the light scattering capability of GZO layers is to increase the $\mathrm{ZnO}$ buffer layer thickness. However, one has to consider also the transparency of the GZO layer, which may be drastically reduced for too thick layers [18]. As a result, the light diffuse transmittance of the film with a GZO $(800 \mathrm{~nm}) / \mathrm{ZnO}(766 \mathrm{~nm})$ exhibited $13 \%$ increase at $420 \mathrm{~nm}$ wavelength due to the larger grain size of the pyramidal texture surface.

In order to be used as front contact in thin film solar cells, electrical property of these $\mathrm{GZO} / \mathrm{ZnO}$ films must be considered, as shown in Table 2. It can be revealed that the increasing of $\mathrm{ZnO}$ buffer layer thickness leads to slight increase in resistivity and slight reduction of carrier concentration of GZO film. Nevertheless, all the GZO films with various $\mathrm{ZnO}$ buffer layer thicknesses exhibit a relatively low resistivity of $10^{-4} \Omega \mathrm{cm}$. In addition, the mobilities of GZO films are increased slightly when increasing $\mathrm{ZnO}$ buffer layer thicknesses due to the pyramid-like grains size being increased which was verified by SEM (Figure 8).

\section{Conclusions}

GZO films with a pyramidal texture surface were successfully developed by the control of (110) preferred orientation. The films exhibited satisfactory optoelectric properties. By employing the low temperature $\mathrm{ZnO}$ buffer layer, we improved the light diffuse transmittance of the film up to $13 \%$ at $420 \mathrm{~nm}$ wavelength. Thus, the obtained GZO films deposited $\mathrm{ZnO}$ buffer layer has high potential for use as front TCO layers in Si-based thin film solar cells. These results could develop the potential way to fabricate high haze TCO thin film using MOCVD or sputtering techniques by depositing a low temperature $\mathrm{ZnO}$ layer to serve as a template.

\section{Competing Interests}

The authors declare that they have no competing interests.

\section{Authors' Contributions}

Nam Giang Nguyen and Van Thi Thanh Ho conceived and designed the experiments and then they analyzed the experimental results and wrote the paper; Long Giang Bach performed the experiments.

\section{Acknowledgments}

The authors would like to thank Professor Lu-Sheng Hong, National Taiwan University of Science and Technology, for the support for this work. 


\section{References}

[1] A. Shah, P. Torres, R. Tscharner, N. Wyrsch, and H. Keppner, "Photovoltaic technology: the case for thin-film solar cells," Science, vol. 285, no. 5428, pp. 692-698, 1999.

[2] H. Sai, H. Jia, and M. Kondo, "Impact of front and rear texture of thin-film microcrystalline silicon solar cells on their light trapping properties," Journal of Applied Physics, vol. 108, no. 4, Article ID 044505, 2010.

[3] M. Berginski, J. Hüpkes, M. Schulte et al., "The effect of front $\mathrm{ZnO}$ :Al surface texture and optical transparency on efficient light trapping in silicon thin-film solar cells," Journal of Applied Physics, vol. 101, no. 7, Article ID 074903, 2007.

[4] O. Isabella, J. Krč, and M. Zeman, "Modulated surface textures for enhanced light trapping in thin-film silicon solar cells," Applied Physics Letters, vol. 97, no. 10, Article ID 101106, 2010.

[5] V. E. Ferry, M. A. Verschuuren, M. C. V. Lare, R. E. I. Schropp, H. A. Atwater, and A. Polman, "Optimized spatial correlations for broadband light trapping nanopatterns in high efficiency ultrathin film a-Si:H solar cells," Nano Letters, vol. 11, no. 10, pp. 4239-4245, 2011.

[6] G. Yue, L. Sivec, J. M. Owens, B. Yan, J. Yang, and S. Guha, “Optimization of back reflector for high efficiency hydrogenated nanocrystalline silicon solar cells," Applied Physics Letters, vol. 95, no. 26, Article ID 263501, 2009.

[7] S. Calnan, J. Hüpkes, B. Rech, H. Siekmann, and A. N. Tiwari, "High deposition rate aluminium-doped zinc oxide films with highly efficient light trapping for silicon thin film solar cells," Thin Solid Films, vol. 516, no. 6, pp. 1242-1248, 2008.

[8] H. Zhu, J. Hüpkes, E. Bunte, J. Owen, and S. M. Huang, "Novel etching method on high rate $\mathrm{ZnO}: \mathrm{Al}$ thin films reactively sputtered from dual tube metallic targets for silicon-based solar cells," Solar Energy Materials and Solar Cells, vol. 95, no. 3, pp. 964-968, 2011.

[9] H. L. Ma, D. H. Zhang, S. Z. Win, S. Y. Li, and Y. P. Chen, "Electrical and optical properties of F-doped textured $\mathrm{SnO}_{2}$ films deposited by APCVD," Solar Energy Materials and Solar Cells, vol. 40, no. 4, pp. 371-380, 1996.

[10] N. Amin, T. Isaka, A. Yamada, and M. Konagai, "Highly efficient $1 \mu \mathrm{m}$ thick CdTe solar cells with textured TCOs," Solar Energy Materials and Solar Cells, vol. 67, no. 1-4, pp. 195-201, 2001.

[11] S. Fay, S. Dubail, U. Kroll, J. Meier, Y. Ziegler, and A. Shah, "Light-trapping enhancement for thin-film silicon solar cells by roughness improvement of the $\mathrm{ZnO}$ front TCO," in Proceedings of the 16th European Photovoltaic Solar Energy Conference and Exhibition (EU PVSEC '00), p. 361, Glasgow, Scotland, 2000.

[12] T. Oyama, M. Kambe, N. Taneda, and K. Masumo, "Requirements for TCO substrate in si-based thin film solar cells -toward tandem," in Proceedings of the Light Management in Photovoltaic Devices-Theory and Practice, vol. 1101 of MRS Proceedings, Materials Research Society, 2008.

[13] M. Kambe, K. Masumo, N. Taneda, T. Oyama, and K. Sato, "Improvement of light-trapping effect on microcrystalline silicon thin film solar cells fabricated on high haze transparent conducting oxides films," in Proceedings of the Technical Digest/17th International Photovoltaic Science and Engineering Conference (PVSEC '07), p. 1161, Fukuoka, Japan, December 2007.

[14] N. Giang Nguyen, V. T. Thanh Ho, and L.-S. Hong, "Lowresistivity, high-transmittance $\mathrm{Ga}: \mathrm{ZnO}$ films prepared through metalorganic chemical vapor deposition using an inexpensive solution of diethylzinc in n-hexane as the Zn precursor," Applied Physics Letters, vol. 102, no. 18, Article ID 181912, 2013.
[15] K. Nishioka, N. Mizutani, and H. Komiyama, "A model for predicting preferential orientation of chemical-vapor-deposited films," Journal of the Electrochemical Society, vol. 147, no. 4, pp. 1440-1442, 2000.

[16] Y. Kajikawa, S. Noda, and H. Komiyama, "Preferred orientation of chemical vapor deposited polycrystalline silicon carbide films," Chemical Vapor Deposition, vol. 8, no. 3, pp. 99-104, 2002.

[17] N. Fujimura, T. Nishihara, S. Goto, J. Xu, and T. Ito, "Control of preferred orientation for $\mathrm{ZnO}_{\mathrm{x}}$ films: control of self-texture," Journal of Crystal Growth, vol. 130, no. 1-2, pp. 269-279, 1993.

[18] S. Faÿ, J. Steinhauser, S. Nicolay, and C. Ballif, "Polycrystalline ZnO: B grown by LPCVD as TCO for thin film silicon solar cells," Thin Solid Films, vol. 518, no. 11, pp. 2961-2966, 2010. 

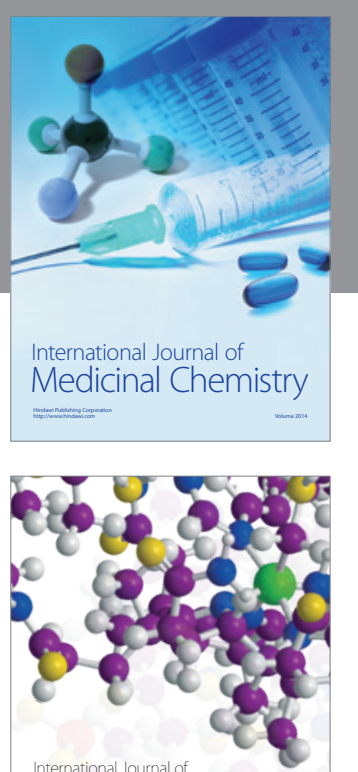

Carbohydrate Chemistry

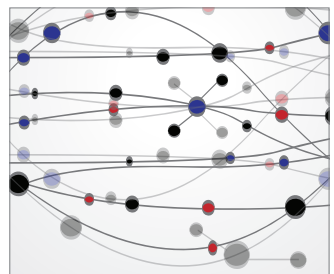

The Scientific World Journal
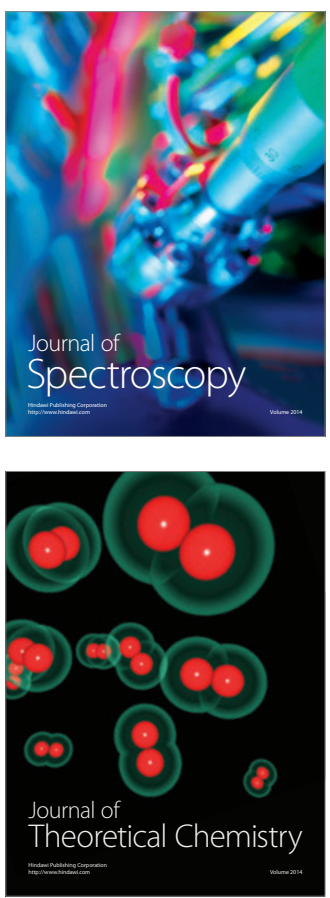
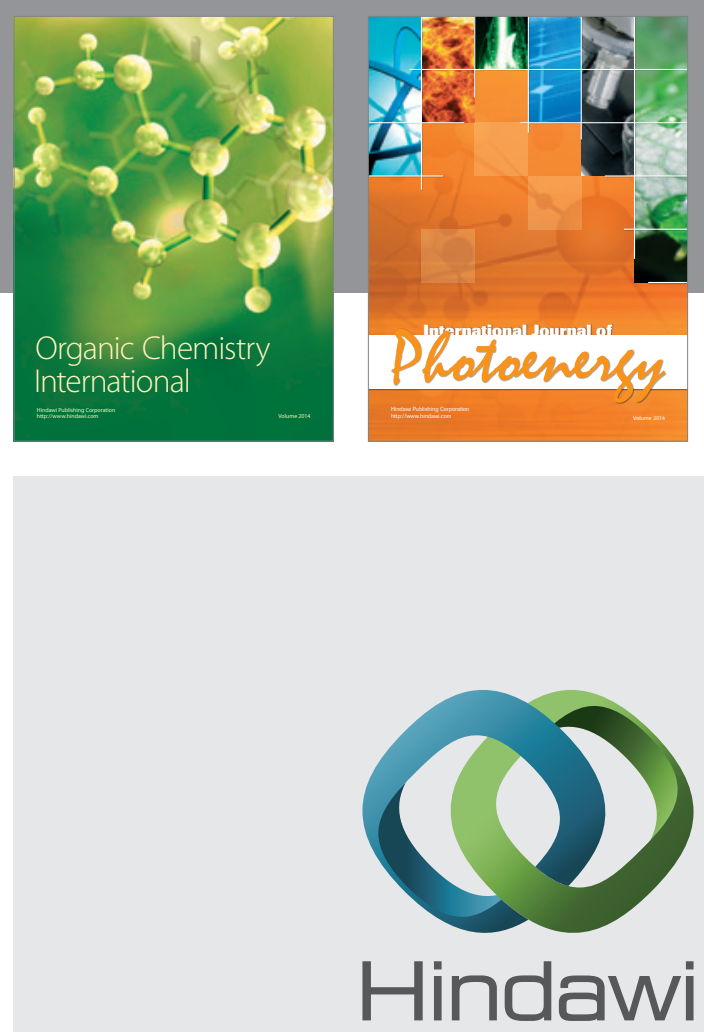

Submit your manuscripts at

http://www.hindawi.com

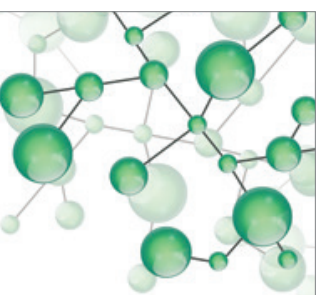

International Journal of

Inorganic Chemistry

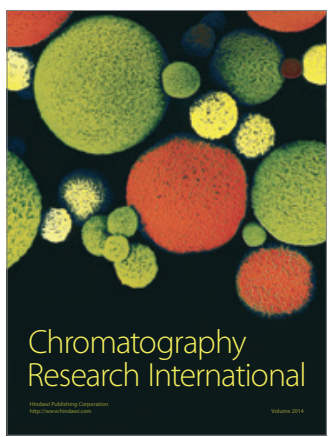

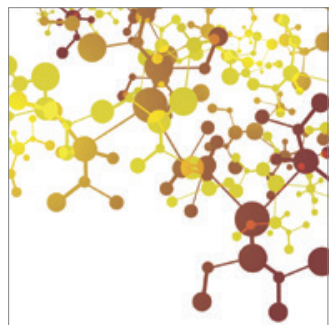

Applied Chemistry
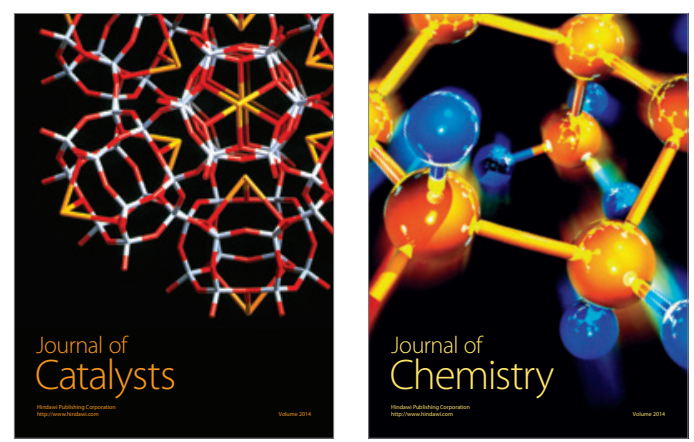
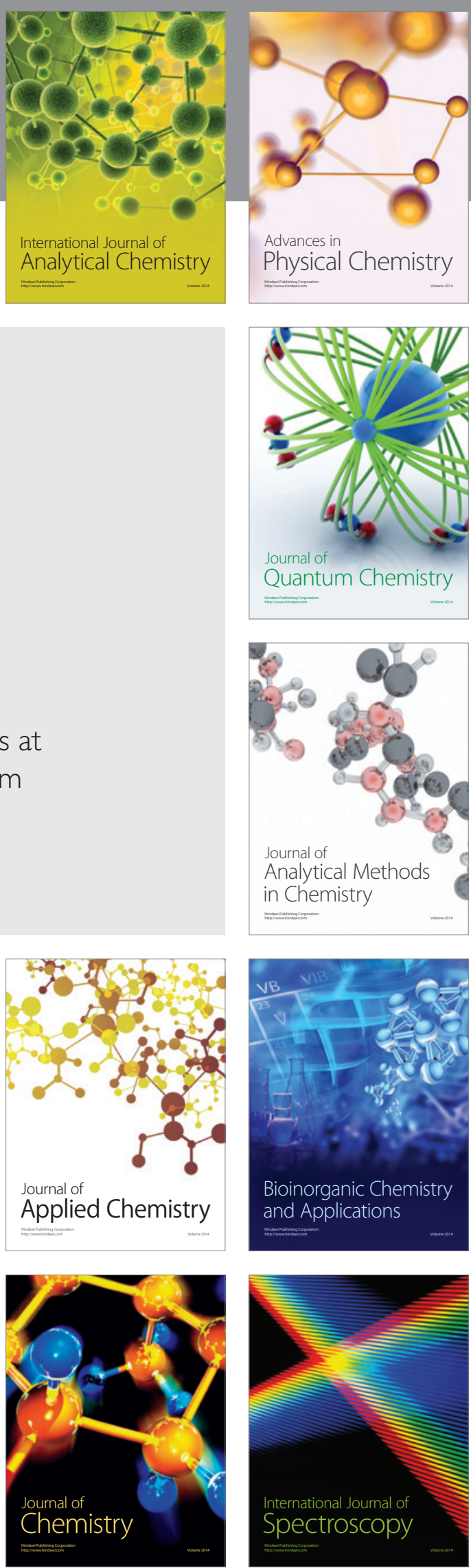